London. This park has cost the country $£ 100,000$. It is surrounded by a very dense population, which terribly needs the park as a place for breathing pure air, apart from all purposes of recreation. If the air is to bc rendered impure by the nearness of the gas-works, then the money of the country will in part have been thrown away, and great injury will result to the population whose benefit was intended. We are sure that no gas-works would have been permitted so near to Thegent's-park or Hyde-park. We sincerely hope that the Lords will not allow a powerful company to be accommodated at the cost of the poor. The Bill is opposed by the Board of Works and by a large and influential minority of the House of Commons. The House appears to have accepted the scheme out of deference to its own committee and not for any liking for it. It is to be hoped that means will be found for prosecuting a determined opposition to the Bill before the House of Lords.

AFren reading through the report of the Scientific Committee on the Cattle Plague we can see no reason why the proposition of treating rinderpest by the injection of whipped and defibrinated blood should not be experimentally tested. The Cattle Plague Commissioners have shown that if the animal sarvive the seventh day of the disease it will probably recover, and that the animal, when it dies, sinks usually from exhaustion and defective nutrition. Dr. Markham, with whom this proposition originates, argues fairly enough that blood, which is food capable of immediate utilization, might help the animal to tide over the time when it is incapable of digesting or assimilating crude food, and he has disposed logically of some theoretical objections which have been urged. The rinderpest is partly extinguished, but it will be long, we fear, before it completely dies out, and it would be a source of regret if the Commissioners, who have power to use any infected animals for experimental purposes, should omit to settle this important question by actual observations. A few experiments would go further than a great deal of discussion.

THE cholera is showing itself all over the world. On the 26th and 27th ultimo more than one hundred deaths occurred at Djeddah. Numerous cases have occurred at Nantes, Rotterdam, and Altenburg. Thirty-five deaths occurred on board the steamer Perurian on her passage from Liverpool to New York, and twenty cases with thirteen deaths in quarantine at the latter port. Another steamer (the Union) from Liverpool had twenty deaths during the voyage. Several cases are stated to have occurred at Liverpool in the most unhealthy part of the town; and one death, after a few hours' illness, at Marsh, near Huddersfield.

A PAPER read at the Academy of Sciences in France estimates the lunatics in France at 84,000-about 1-429th of the whole population. It is stated also that of that number only 358 cases were traceable to intense mental application. In France, says a writer who comments upon this, dissipation, absinthe, and speculation are the predominant causes of the major part of the cases of mental aberration. We apprehend that a similar statement might be justly applied to almost every other country in the world.

\section{THE VACCINATION BILL.}

To the Honourable the Commons of the United Kingdom of Great Britain and Ireland in Parliamont assembled.

The petition of the undersigned, on behalf of the Manchester Medico-Ethical Association,

Humbly sheweth,--That it is of great national importance that universal and compulsory vaccivation shall be established by law.
That a Bill is now before your honourable House which has for its object the attainment of this end.

That the Bill, while highly commendable in its ultimate aim, is defective or erroneous on the following points :-

1. That no public prosecutor of persons evading its enactments is provided for, without whom it is likely to become almost a dead letter.

2. That the rate of remuneration awarded to the public vaccinator is insufficient, more especially as it affects the country medical practitioners.

3. That the compulsory demand (enforced by penalties) from all medical practitioners of professional service to the State without remuneration, is an oppression of one class of the community for the benefit of the rest, and contrary to the whole spirit of British legislation.

4. That no adequate provision is made for a sufficient and periodical supply of vaccine lymph from the cow.

Your petitioners, therefore, humbly pray that your honourable House will pass such a measure as will secure this country from the ravages of so dreadful a malady as small-pox, and that the four points above-named may at the same time obtain your earnest consideration.

And your petitioners will ever pray.

Signed on behalf of the Manchester Medico-Ethical Association,

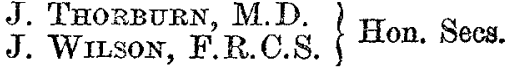

\section{THE MEDICAL A C T.}

To the Editor of Tere LANCET.

SIR,-I beg to forward you a copy of a petition which was presented by Colonel North, M.P. for Oxfordshire, on the 7th inst. Yours obediently,

Banburs, June 8th, 1866.

Artirur B. RYE.

\section{To the Honourable the House of Commons in Parliament} assembled.

We, the undersigned legally qualified practitioners residing and practising in the town of Banbury and its neighbourhood, were by an Act, 2nd August, 1858, required to register under such Act; and upon producing our certificates we, upon a payment of money, were registered accordingly.

Now we complain that by an informality of this Act it is totally inoperative, inasmuch as, by a legal difficulty in the clause No. 40, an unregistered person practising here is allowed to assume a title to which we hold he has no right, inasmuch as the Medical Council under your Act have totally ignored and refused to register it.

Also, seeing that your honourable House is about to pass an Act to prevent unlicensed veterinary surgeons-that is, those who treat the complaints and, as now, preside over the lives of the brute creation-from practising their art without due examination and proper licence, and supposing that the lives of her Majesty's subjects may be held of equal value and entitled to the same protection, we, in our humble capacity, can but urge it as a fair supposition that, in your legislative wisdom, you will so far amend the present Medical Act of 2nd August, 1858, as to afford to those practitioners qualified under it that protection which they have expected by a registration under its requirements, which it was no doubt intended to supply, but which from its imperfect construction it has hitherto so signally failed to effect.

And your petitioners will ever pray.

(Signed) ARThUR B. RYe, F.R.C.S., Bankury.

JoHN GRIFFIN, M.D., M.R.C.S., do.

Sherman Chesteritay, M.R.C.S.

Clarence L. Pemberton, Banbury.

EDward Franex, M.R.C.S., do.

RichaRd GRIMBLY, M.R.C.S., do. W. W. HyDE, M.R.C.S., Bloxham. John Colmgrave, M.R.C.S., do. J. MacGreal, M.R.C.S., Alkerton. W. T. DodGLAS, M.R.C.S., Banbury. R. S. WISE, M.D. do. Geo. Fayrer, M.D., Henley in Arden. Tromas Clarke, M.R.C.S., Banbury.

* Medical practitioners in all parts of the kingdom might with advantage adopt a suitable form of petition in favour of the Medical Acts Amendment Bill, and forward it to their respective representatives, with an urgent request for support. 
Representations might also be properly made to the Home Secretary, who shows so little earnestness on the subject, has delayed the Bill so seriously, and has even suggested that the Government will be reluctant to trouble themselves with the mensure. 'The reference to the Veterinary Surgeons' Bill in the above document is hardly judicious. That is a private Bill, and it is by no means certain, as is here assumed, that it will pass. The Government ought to learn, however, that the medical profession and the public are earnest about this matter. The feeling in the daily press is quite as strong as that which we ourselves entertain, and public protests against further delay addressed to ministers, in suitable and respectful language, either by deputations, or in Parliament, would meet with a general and powerful response.-ED. $\mathrm{L}$.

\section{Corxtspomdente.}

"Audi alteram partem."

\section{THE SPHYGMOGRAPH IN ENGLISH MEDICAL PRACTICE.}

To the Editor of THE LANCET.

$\mathrm{SrR}_{\text {, }}$-The letter of Dr. Foster in reference to your strictures on his pamphlet on the Sphygmograph requires a brief notice from me.

I can assure Dr. Foster that neither Dr. Sanderson nor myself have any wish whatever to claim any merit for " introducing" to the notice of the English medical profession an instrument which has, in fact, been public property for several years past.

As regards the question personal to myself, I have only the following remarks to make :-It has been publicly stated in various quarters, and is now repeated by Dr. Foster, that his paper was the first account of the uses of the sphygmograph published in this country. The fact is. on the contrary, that an analysis of a paper read by me at the Medical Society of London was given, editorially, in The LANCET of Nov. 26th, 1865, occupying a prominent position, where it could hardly escape notice.

My friends in London well know that I have taken great pains and sacrificed much time in inducing as many observer as possible to work with the sphygmograph, and to keep reeords of cases; and I should deem it absurd to claim merit for merely informing English physicians of facts which are to be found in so accessible a work as M. Marey's well-known book. But I certainly consider that it would have been proper for Dr. Foster, at a time when paragraphs had appeared in more than one widely-circulated journal, which gave him credit as the originator of what has been done with the sphygmograph in this country, to have disclaimed that honour in the only effective way. That way rould have been to refer inquirers specifically to the editorial analysis of my paper published in THE LANCET in November last-an article which contains not merely a recitation of M. Marey's conclusions on many important points, but also certain original conclusions of my own, which were based on a large number of clinical sphyg mographic observations made by Dr. Sanderson and myself

I would beg, finally, to express the confident expectation that, by the united efforts of the numerous English sphygmographers now at work, the instrument will be made to render the most important services to clinical research.

I am, Sir, your obedient servant,

Wimpole-street, June 11th, $1866 . \quad$ Francis ED. Anstre.

\section{POOR-LAW MEDICAL REFORM.}

\section{To the Editor of THE LANCET.}

Sir, - I shall feel obliged by your allowing me, throngh the medium of your journal, to inform the Poor-law medical officers, and I may say the profession generally-for it concerns all, - that the Vaccination Bill has passed through the Select Committee, and is again before the House of Commons.

In my communications to the Select Committee I suggested alterations in the title and preamble and in nineteen clauses, or proposed to substitute nine new clauses. On examining the Bill, I find the title and preamble still stand without Wales being mentioned; but twenty-three clauses have been altered, verbally and otherwise, and one clause (the 5th) added. The four forms in the schedule have also verbal alterations. Allow me here to state, howcver, that all my suggestions have not been adopted.

With due appreciation of the value of the efforts made by the meeting held at the Freemasons' Tavern on April 10th, and by private individuals, still it appears to me that the efforts made by the Poor-law Medical Reform Association have had considerable influence-first, in actually stopping the Bill when about to so into committee of the House of Commons, by means of a pamphlet forwarded to each member and by private communications; and secondly, by suggestions made to the Select Committee itself. But that influence could never have been made to bear, had not money been subscribed to pay the expenses of printing \&c. I have no hesitation in saying that the amendments now proposed in the Vaccination Bill will amply repay the members of the Poor-law Medioal Reform Association, in a pecuniary point of view, for all the money they have subscribed during the last ten years; and $\mathbf{I}$ hope will stimulate the entire body of Poor-law medical officers. to subscribe to the funds of the Association, in order to enable it to prosecute with vigour the changes sought in the general administration of the medical relief of the poor. The seed has been sown; the eyes of the public have been opened; a large portion of the members of the House of Commons now listen to us. and the time cannot be far distant when very considerable changes must be made in the medical relief of the poor.

Clauses 5 and 6 in the amended Vaccination Bill (quoted last week) will show the pecuniary changes proposed. On and after January 1st, 1867, the public vaccinators are to receive not less than 18.6d. for each successful primary vaccination performed in a workhouse. This is a gain, as at present no fee is legally payable. The $1 s .6 d$. fee now paid for vaccinations performed at a station within one mile of the residence of the medical officer is not increased; but $6 d$. is added to each fee for all vaccinations performed at a station over one mile and under two miles distant, thus making the fee 28 . Beyond two miles, the fee, which is now $2 s, 6 d$., is to be not less than 3s. In addition to these payments, it is proposed by Clause 5 to pay 1s. extra for each child whom the vaccinator has successfully vaccinated; but that will depend on the "number and quality" of the vaccinations, on the "reports" made to the Lords of H.M.'s Council, and the time to which the "award" relates.

This clause is ambiguous, but on inquiry I find the payment is intended to depend upon the manner in which the vaccination is carried out that is, if done in accordance with the apprcval of the inspectors. My correspondent says, "If you glance at any of the inspectors' reports, you will see on what system they go in judging the vaccination of a place, and by their reports the medical officer of the Privy Council would be guided to recommend the payments in question. They would be additional payments, made on the principle of payment for results. I hope it will be of general benefit to the public vaccinator, whose interests will be identical with those of the public." "The revaccination of those previously successfully vaccinated will be under special arrangements, and only paid for at two-thirds of the fee of successful primary vaccination.

I regret we have not obtained more; but if we do our duty well, and Clause 5 be fairly carried out, the Bill will be a gain to us of some thousands per annum, and I feel sure will place the public vaccination of this country on a more satisfactory footing. That the Bill might have been more efficiently amended cannot admit of a doubt; but official influence was too strong for us; and a satirical print (worth looking at) by Standidge and $\mathrm{Co}$, forwarded to me by a member of the Select Committee, representing the Poor-law vaccinators receiving $£ 200,000$ a year-the registrars $£ 20,000$ a year-Simon, Bruce, and Co. $£ 10,000$ a year, \&c., had its weight in preventing oux receiving that redress we desired.

I have again addressed the Poor-law Board, asking that a deputation of Poor-law medical officers may be permitted to wait upon them on July 5th, which I trust may be granted. I am, Sir, yours \&c.,

I2, Royal-tcrrace, Wermouth, June 11th, 1866 RICHARD GRIFHIN,

The French Government have adopted precantionary measures in consequence of the cases of cholera which have recently occurred in Djeddah and Meccs. 